\title{
排出分布を考慮したプラスチックリサイクルの経済性評価
}

-2001.8 .30 受理一

京都大学 町田 宗太 ${ }^{* 1}$, 手塚 哲央*1, 佐和 隆光*2

1. はじめに

近年, 資源節約, 環境保全, 廃棄物処分場不足解消 などを目的として，リサイクル導入の機運が高まって いる。そして制度面からも循環型社会形成推進基本法 を初めとした各種りサイクル関連法が制定され、リサ イクル導入の動きが本格化しつつあるといえる。

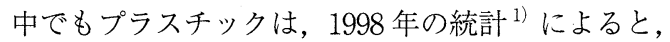
一般廃棄物中では主に容器包装の形で年間 499 万 t, 産業廃棄物として年間 485 万 t，合計年間 984 万 t が 国内で排出されている。そして，一般廃棄物の中では 重量比で 10\% 程度を占めている。

この多量のプラスチックは, 枯渇性の化石資源から 作られ，また腐敗しないために環境破壊の原因となる ことから，排出抑制やリサイクルが強く求められてい る。そのため, 容器包装リサイクル法が制定されると ともに, プラスチックの各種リサイクル技術の開発が 進められ, 数多くのリサイクルプラントも稼動中であ る。しかし, 特に一般廃棄物中のプラスチックはその 種類も多様であり, PET ボトルのような特殊な例を 除いて分別回収が困難である場合が多い。

このプラスチックのリサイクルには，2つの視点が ある。一つは, 省資源, 省エネルギーおよび環境負荷 削減の物理的特性の観点から，どのようなリサイクル 技術が望ましいかを探ることであり，数多くの LCA

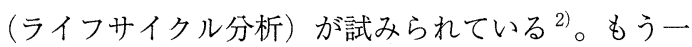
つが，リサイクルに伴う支出の問題である。リサイク ル行動の主体が企業や地方自治体であるため, 費用と いうミクロ経済的視点から見て, 各リサイクル技術が

\footnotetext{
* 1 大学院エネルギー科学研究科 エネルギー社会・環境科学専攻

* 2 経済研究所 京都市左京区吉田本町
}

実現可能であるか否かが重要な問題となる。

そこで本論文では，一般廃棄物に含まれるプラスチ ックの各種リサイクル技術をミクロ経済的視点から評 価し，省エネルギー性の評価結果と組み合わせること により，効果的なりサイクル方策のあり方について検 討することを目的とする。

ゴミの収集運搬費用の算出についてはいくつかの研 究事例が存在するが ${ }^{2}$, それらは積み上げ法で費用の 推定を行ったものである。すなわち，単純な構造をも つ仮想都市モデルを想定して，必要となるゴミ収集車 の台数や作業員数を算出し, それに車両費や人件費を 掛け合わせて収運費用を求めている。しかし，この方 法では，モデルと現実の状況との乘離を補正すること ができず計算結果に実際の費用との大きな誤差を生じ る可能性が高い。

ところで，過去のゴミ行政においても，また容器包 装リサイクル法においても廃プラスチック収集の中心 となっているのは地方自治体である。そこで本研究で は，各自治体の実際のゴミ収集予算を基礎とし，プラ スチックリサイクルを導入した場合の収集状況（積み 上げ法により推定された収集車の往復回数, 走行距離 及びそれに要する時間など）の相対的な変化から，収 運費用の変化分を推定することとした。

以下，2節では，近畿圈の大都市を含む大阪府と京 都府を対象として，廃プラスチックの現状における排 出, 収集, 処理形態を、地域メッシュ統計に基づいて モデル化する方法を述べる。また，モデル化の結果を 3 節に示す。そして，4節および5節においては，各 種プラスチックリサイクルシステムの導入効果を，3 節までのモデル化結果と個々のリサイクル技術特性を 用いて，省エネルギー性と経済性の両面から評価した 結果について述べる。そして，6節では，これらの分 
析結果に基づいて, 今後のリサイクルのあり方と地域 行政のかかわり方を考察する。

\section{2. プラスチック排出のモデル化}

本研究では, 京都府と大阪府を対象として, 国勢調 査及び事業所・企業統計調査結果を, 基準地域メッシ ユ区画（ほぼ $1 \mathrm{~km}$ 平方の区画）ごとに集計した地域 メッシュ統計 4) 5) , 世带数別㧍よび業種別のゴミ組成 データ ${ }^{6)}$ ，および，市町村別廃プラスチック排出量統 計 ${ }^{7)}$ を基に，廃プラスチックの排出分布図をプラス チックの種類別に作成する。一例を Fig. 1 に示す。な お，家庭ゴミに関しては世带別人口分布に基づいて， 事業系ゴミに関しては業種毎の排出原単位 ${ }^{6)}$ に基づ いて，地域メッシュごとの排出分布を推定する。また， プラスチックの種類は, 生産量の多いPE（ポリエチ レン), PP (ポリプロピレン), PS (ポリスチレン), PVC (ポリ塩化ビニル), PET (ポリエチレンテレフ タレート)の 5 種類に, それ以外のプラスチックであ る「その他」を加えた計 6 種類に分けて取り扱う。な お，PVDC（ポリ塩化ビニリデン）は PVCに含める ものとする。

推定されたプラスチックの排出量分布においては, プラスチックの種類別排出割合に地域差はほとんど観 察されない。これは，人口密度や事業所密度に基づい てモデル化していることによると考えられる。ただし， 人口密集地では単身世帯が多いことから一人当たりの 排出量も多く, 京都市のプラスチック排出量は京都府 全体の排出量の約 60\% であり, 京都市の京都府にお ける人口比約 $55 \%$ を上回っている。

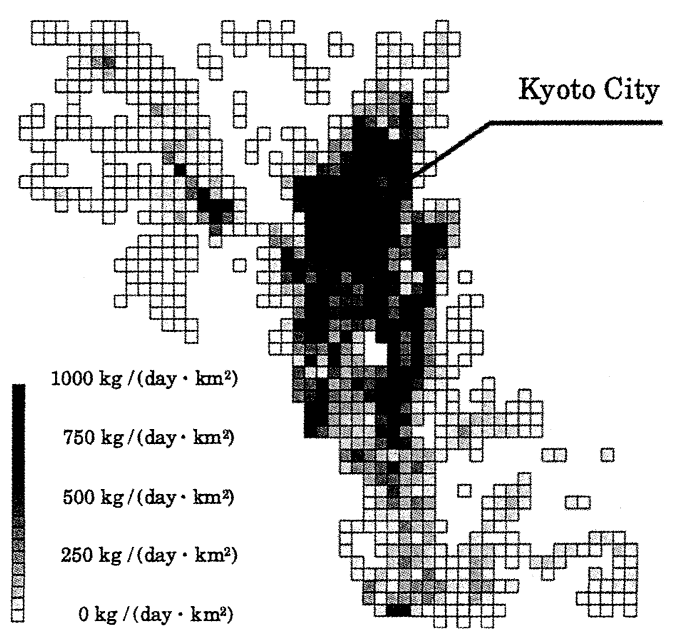

Fig. 1 Distribution of plastics waste in southern area of Kyoto prefecture
また, Fig. 2 に示すように, 種類別排出量について は前述の 5 種類のプラスチックで大半を占めているこ とが分かる。しかし, 最も多いPP（ポリプロピレン） で $36 \%$ 程度であり, 特に際立って使用量の多いプラ スチックは存在しない。廃プラスチックをペレット化 し樹脂として再生利用する場合には, 対象となる廃プ ラスチックが同一の種類でなければ高品質の樹脂は得 られない。このように多くの種類のプラスチックが少 量ずつ分散していると, 一定量の単一種の廃プラスチ ックを収集する費用の増大が予想される。

次節では, 得られた廃プラスチックの種類別排出分 布を用いた廃棄物の収集, 処理に伴うエネルギー消費 量および費用の評価方法について述べる。

\section{3. 各種処理技術と収集広域化について}

容器包装の廃プラスチック排出量は一般廃妄物中に 体積比で $43 \%$ を占めるものの, 重量比では $10 \%$ とな る7)。そのため廃プラスチックだけをある一定重量集 めるためには収集エリアを一般ゴミ回収の場合よりも 広域化する必要が生じる。また, 現在稼動している廃 プラスチックのリサイクルプラントは, 年間処理量数 千トンと比較的多量の廃プラスチックの供給を必要と していることから, 廃プラスチックのリサイクルプラ ントには, ある程度の「規模の経済」が存在すると考 えられる。そこで、プラント規模を現状のプラント規 模と同様とした場合に, 各種リサイクル技術がそれぞ れどの程度の広域化を必要とするのかを算出し, 廃プ ラスチックの収集運搬時のエネルギー消費量や費用の 評価を行う際の基礎データとする。

本研究で検討したリサイクル技術は, 非エネルギー 製品としての「再生利用」と, エネルギーリカバリー の一種とみなせる「油化」「「RDF（Refuse Derived Fuel）化」,「ゴミ発電」の 4 ケースであり, 以降の各 種検討も, 基本的にこの 4 ケースに従来型の「焼却処

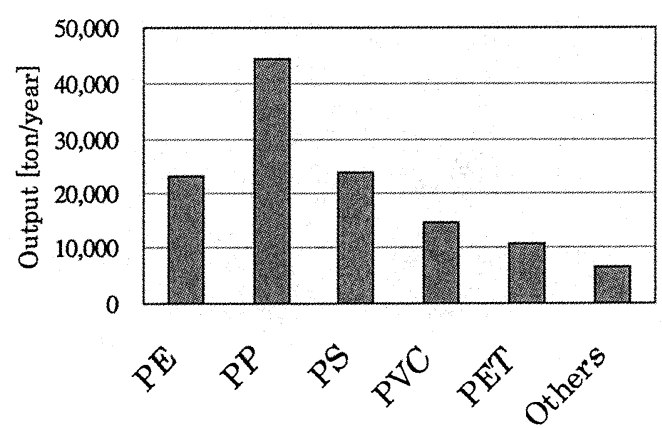

Fig. 2 Plastics waste in Kyoto prefecture 
理」を加えたものを対象として行う。なお，RDF化 ではプラスチック単独での処理を，ゴミ発電では他の 可燃ゴミと混合した状態での処理を考える。

まず，ゴミ収集モデルについて説明する。

\section{1 プラスチック収集のモデル化}

ゴミ収集については，複数の世帯が 1 つのゴミ集積 所を利用し，そのゴミ集積所間を収集車が巡回する形 式を想定する。

ゴミ集積所の設置方法については，実際の人口分布 に基づいて，人口（昼夜間平均人口） 40 人当たりに 1つのゴミ集積所を設置することとする。ただし，人 ロが 40 人未満の $1 \mathrm{~km}$ メッシュ区画でも一つのゴミ集 積所を設置するものとし, 人口が過度に密集している 地域では，ゴミ集積所間の最小距離を $20 \mathrm{~m}$ とする。

次にゴミ集積所の設置方法については, Fig. 3 に示 すように格子状に均等に配置し，それらのゴミ集積所 を収集車が最短ルートで回ると仮定する。

収集し終わった収集車は，その市町村が現在所有し ている処理場あるいは契約している処理場に，該当す る処理場が複数存在する場合は最短の処理場に, 処理 場が広域化されている場合は広域化対象となっている 処理場に，それぞれ収集したゴミを運搬する。なお， 現存しない各種リサイクルプラントも，上記の処理場 に隣接されて設置されるものとする。

この処理場までの往復運搬距離については，道路が メッシュ区画と同じように $1 \mathrm{~km}$ 間隔で格子状に存在 すると仮定し，この格子状の道路を通って処理場まで を往復したときの距離を「処理場までの運搬距離」と した。このごみ収集のモデル化手法はグリッドシティ モデル3）と呼ばれている。

以上により，プラスチック収集時においてトラック 1 台が 1 回往復するときの運搬距離が算出できる。こ の運搬距離をゴミ種別ごとに設定される収集車（2卜
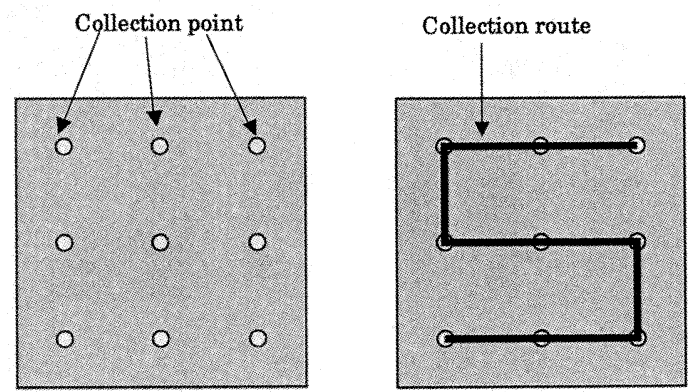

Fig. 3 Route of garbage collection
ン車)の積載量で割ると，単位排出量当たりの運搬距 離が求められる。これを，ゴミ排出量増加に対する運 搬距離増加率 $[\mathrm{km} / \mathrm{t}]$ と考える。なお，2卜ン車の プラスチック積載可能量は各プラスチックの比重と形 状より，PETのみを分別する場合は $75 \mathrm{~kg} /$ 台，その 他のプラスチックについては $340 \mathrm{~kg} /$ 台と想定した。

この運搬距離に基づいて, 収集に要する時間が算出 される ${ }^{3)}$ 。運搬時間は次の 3 つの時間よりなる。即ち, 処理場までの往復に掛かる時間，ゴミ集積所間を移動 する時間，そしてゴミ集積所でゴミを収集車に積み込 む時間である。このうち，処理場までの往復時間とゴ ミ集積所間の移動時間は，それぞれの移動距離をそれ ぞれの平均移動速度で割ることにより求められる。具 体的には，文献3）に揭載されている測定結果から, ゴミ集積所での積み込み時間については単位時間当た りの積み込み量を $0.395 \mathrm{~kg} /$ 秒とし，処理場間の平均移 動速度を $24.0 \mathrm{~km} /$ 時, ゴミ集積所間の平均移動速度を $15.7 \mathrm{~km} /$ 時として計算した。

なお，収集頻度については，焼却処理とゴミ発電に 関しては週 2 回，その他の処理方法に関しては月に2 回の収集を想定する。これは，現状と同程度の収集頻 度となっている。

次に, この収集モデルに基づく計算結果を処理方法 ごとに示す。

\section{2 ゴミ発電}

ダイオキシン対策やサーマルリサイクル推進等の必 要性から, 厚生省では各都道府県に対してゴミ処理の 広域化を指導している ${ }^{12)}$ 。この厚生省主導の広域化 計画では, 可能な限り焼却能力 $300 \mathrm{t} /$ 日以上（最低 でも $100 \mathrm{t} /$ 日以上）の全連続式ゴミ焼却施設を設置 するよう求めている。そこで, ゴミ発電については, 現在, 広域処理計画の対象となっているプラントでゴ ミを処理するものとした。

\section{3 再生利用 (PET)}

各種プラスチック製品の内, PET ボトルは他のプ ラスチック製品と比べて再生利用が容易であり, 容器 包装リサイクル法ではこの PET ボトルを他のプラス チックに先駆けて 1997 年度から再商品化義務対象と した。そのため，既に 2000 年現在で数十の PET ボト ル再生プラントが建設され稼動中である。そこで, 本 研究では, PET ボトルのみを再生利用の対象とする。

PET ボトルのリサイクルプラントは, 8,000t / 年程 度の処理能力を持つものが多い ${ }^{10)}$ 。そこで，この 
$8,000 t /$ 年の処理能力を持つプラントが京都府下並び に大阪府下に設置された場合に，どの程度の処理の広 域化が必要となり加重平均収集運搬距離が長距離化す るかについて検討した。

なお, PET ボトルの全国での平均回収率は 1998 年 で $16.9 \%$ と少ないが8)，これはPET ボトルの回収を 実施している地方自治体が少ないためである。PET ボトルの回収を行っている自治体である神奈川県小田 原市 (人口約 20 万人) の PET ボトル排出量 ${ }^{10)}$ では 約 8 割の回収率が報告されている。そこで, 本研究で はPET ボトルの回収率を $80 \%$ と仮定して以下の検討 を行った。

まず PET ボトルの京都府と大阪府における収集可 能量を Fig. 4 に示す。京都府下ではようやく $8,000 t /$ 年 の規模のプラントを一基満たすだけの PET 回収量が 得られる程度に留まり, 収集のためのエネルギー消費 量や費用負担が大きくなると予想される。一方，大阪 府下では 8,000t / 年の規模のプラントを 4 基設置可能 となり，1プラントあたりの収集面積も狭くなるため 収集の面で京都府に比べて有利であるといえる。

なお，京都府下で PET ボトル再生プラントを 1 基 建設した場合では，廃プラスチック排出分布図より算 出した廃 PET ボトルの加重平均収集運搬距離が $19 \mathrm{~km} / \mathrm{t}$ となり, これは現状の焼却処理の場合に扔け る $5 \mathrm{~km} / \mathrm{t}$ を大幅に上回る。

\section{4 油 化}

廃プラスチックの油化技術は，PE，PP，PS 等一般 廃棄物中の廃プラスチック全体の $70 \%$ 以上に適用で き, PETの再生利用と比べて対象となる廃プラスチ ックの収集量が多くなるため, 1 プラント当たりの収 集エリアを狭く取ることが出来る。

現在の主な油化プラントは $6,000 t /$ 年程度の処理能 力が主流であることから ${ }^{11)}, 6,000 t /$ 年の油化プラン 卜を対象として, PET の再生利用と同様の方法で油

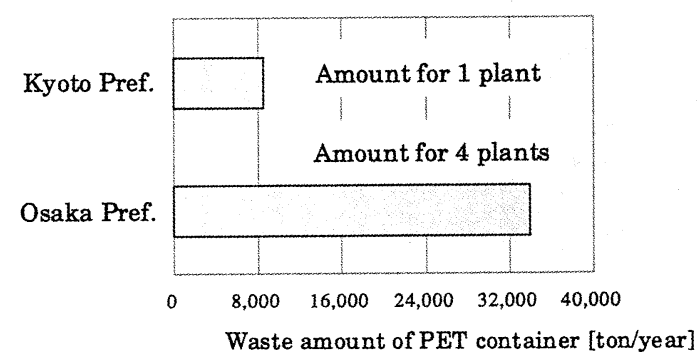

Fig. 4 Waste amount of PET container
化用のゴミ収集について検討した。

京都府と大阪府における油化用プラスチックの収集 可能量を Fig. 5 に示す。この結果によると京都府下で は 12 基, 大阪府下では約 50 基の油化プラント建設が 可能となる。すなわち収集面については, PETの再 生利用と比較した場合には極めて有利であり, 現状の 焼却処理（京都府下の焼却処理施設は23 箇所）と比 較しても収集面で不利にはならない。

なお，油化用廃プラスチックの加重平均収集運搬距 離も $6 \mathrm{~km} / \mathrm{t}$ となり, 焼却処理の場合とほぼ同程度の 距離となる。

\section{5 RDF 化}

$\mathrm{RDF}$ 化処理では全てのプラスチックが利用可能で あり，かつ RDF化プラントは再生利用や油化のプラ ントよりも小規模化が可能となる。そのため, ごみ発 電と同様の広域化を想定する。すなわち, 収集の運搬 距離に関してもごみ発電の場合とほぼ同程度となると 考えられる。

以上に述べた処理技術別収集方法の前提条件を Table 1 にまとめて示す。そして処理方法別の加重平 均収集運搬距離の推定結果を Fig. 6 に示す。再生利用 の収集運搬距離が突出して長くなることを除くと, 収 集運搬距離は現状の焼却処理と同程度となることが分 かる。

\section{4. プラスチック処理のエネルギー評価}

廃プラスチックをリサイクルする目的としては，廃 棄物の埋立量を減らすと共に，エネルギー資源を節約 することも重要である。その省エネルギー効果を調べ るためには, ライフサイクルエネルギーの視点に基づ いた評価が必要となる。

そこで本論文では，まず廃プラスチックの収集運搬 に伴うエネルギー消費量を推計する。すなわち，家庭 や事業所から排出される廃プラスチックを収集し処理

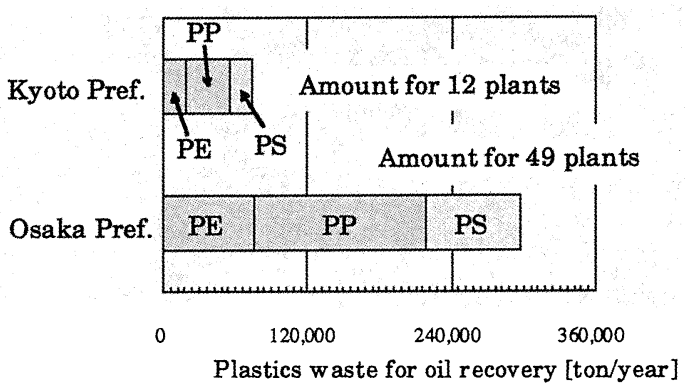

Fig. 5 Plastics waste for oil recovery 
Table 1 Assumptions sbout collection modeling

\begin{tabular}{|c|c|c|c|c|}
\hline & $\begin{array}{c}\text { Garbage } \\
\text { Fractionation }\end{array}$ & $\begin{array}{c}\text { Pay load } \\
\text { for Plastics }\end{array}$ & $\begin{array}{c}\text { Frequency of } \\
\text { collection }\end{array}$ & Plant location \\
\hline Incineration & \multirow[t]{2}{*}{ combustible } & & \multirow[t]{2}{*}{$2[$ times/week $]$} & $\begin{array}{c}\text { locations of the } \\
\text { plants currently in } \\
\text { operation }\end{array}$ \\
\hline Garbage power & & & & \multirow{4}{*}{$\begin{array}{l}\text { locations of the } \\
\text { plants for wide-area } \\
\text { collection }\end{array}$} \\
\hline Oil recovery & PE, PP, PS & & \multirow{3}{*}{$2[$ times/mouth $]$} & \\
\hline $\mathrm{RDF}$ & all plastics & & & \\
\hline $\begin{array}{c}\text { PET } \\
\text { Reclamation }\end{array}$ & PET container & $85 \mathrm{~kg}$ & & \\
\hline
\end{tabular}

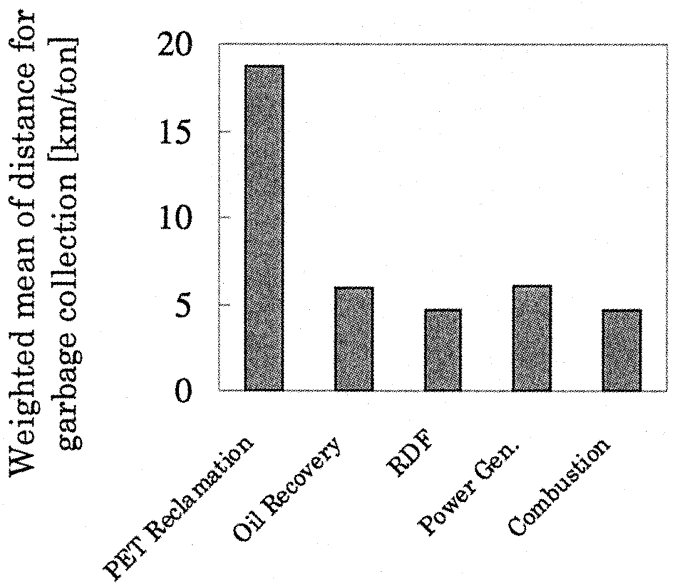

Recycling technologies

Fig. 6 Weighted mean of distance for garbage collection by recycling technology

場まで運搬するために必要となるエネルギー消費量 （以下では，収集エネルギーと呼ぶこととする）を， 廃プラスチック処理技術ごとに廃プラスチックの排出 分布に基づいて推定する。そして，収集エネルギー以 外のエネルギー消費量に関しては，既存の LCA 研究 のデー夕を参照することにより，エネルギー消費量の 面からの総合的な評価を行う。

\section{1 収集エネルギー}

前節において, 各種廃プラスチック処理技術の広域 化案を基に，それぞれ設置可能な数の処理施設を配置 し，廃プラスチックの排出地点から処理場までの加重 平均距離を算出した。この加重平均距離と収運トラッ ク 1 台当たりの平均積載量とに基づいて, 廃プラスチ ック収集に伴うエネルギー消費量を求めることができ る。ただし，トラックの燃費を軽油 1 リットルあたり $3.5 \mathrm{~km}$ とした。

現状の，混合ゴミとして他のゴミと混ぜた状態で廃
プラスチックを排出するケースと, 厚生省指導の広域 化によりゴミ発電を推進したケースでは，収集エネル ギーはいずれも $300 \mathrm{~kJ} / \mathrm{kg}$ 程度であり，廃プラスチッ クが持つ熱エネルギー約 $40,000 \mathrm{~kJ} / \mathrm{kg}$ と比較して非常 に小さな値にとどまっている。また，RDF化および 油化に関しても，一度に収集できる積載量が比較的多 く，運搬距離も短いために収集エネルギーはゴミ発電 の場合とほぼ同じ値となる。

一方, 再生利用の場合では一回当たりの収集量が低 く運搬距離も長いため, 収集エネルギーは $1,400 \mathrm{~kJ} / \mathrm{kg}$ と多くなるが，この場合でも収集エネルギーがプラス チックのライフサイクルエネルギーに占める割合は後 述するように非常に小さくなる。

\section{2 処理技術全体のエネルギー評価}

廃プラスチックの各種処理技術に関するライフサイ クルエネルギーの分析結果として社団法人プラスチッ ク処理促進協会の報告 ${ }^{13)}$ 14）を取り上げ，本研究で算 出した収集エネルギーを組み合わせて，各処理技術の ライフサイクルエネルギー評価を行った。

PET に関する推定結果を Fig. 7 に示す。PET ボト ルは，その再生利用によりバージン材の製造に比べて $1 \mathrm{~kg}$ 当たり約 $60,000 \mathrm{~kJ}$ のエネルギーを節約でき，エネ ルギー消費量の点から見て最も有利な処理方法である ことが示される。そして, 収集エネルギーについては, 前述したようにリサイクルシステムのエネルギー評価 にはほとんど影響を及ぼさないことが理解される。

ただし, 再生品の品質はバージン材より劣り, 同一 の製品として利用できないことに留意する必要があ る。この再生品の品質による用途の違いは，本論文で は評価に含められていないが，今後検討すべき事項の 一つである。

$\mathrm{PE}$ な゙の, PET 以外のプラスチックに関しては, 現在再生利用の実例に乏しいことから，エネルギーリ 


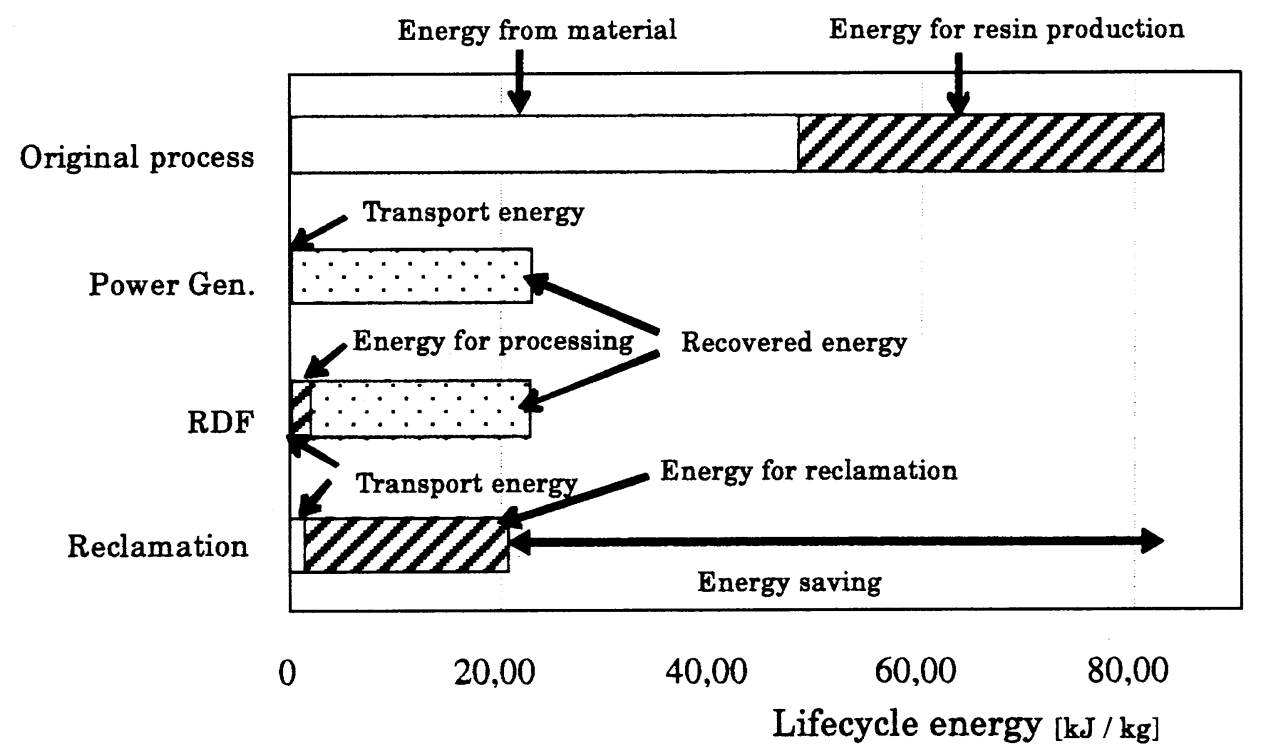

Fig. 7 Lifecycle energy of PET recycling

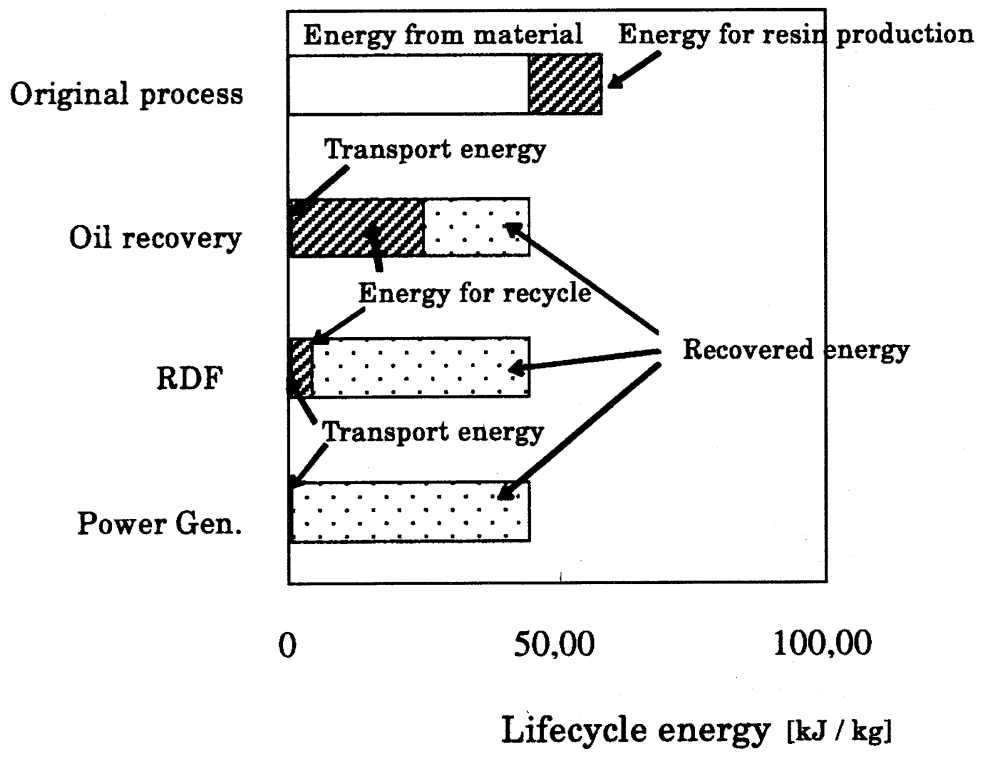

Fig. 8 Life-cycle energy of PE recycling

カバリー技術の適用を考え, 油化, RDF化，ゴミ発 電について PET ボトルと同様の手順で評価した。た だし，前述したように油化については，PS，PP，PE のみの適用を考える。

Fig. 8 に，PEに関する各種リサイクル技術のライ フサイクルエネルギーの分析結果を示す。PETの場 合と同様，処理システム全体のエネルギー評価におい て収集エネルギーの占める割合が極めて低いことが分
かる。すなわち，エネルギー消費量の観点からは収集 エネルギー評価の重要度は低いといえる。

また, 油化に関しては加工時におけるエネルギー投 入量が多く, 正味の得られた燃料としての発熱量は $\mathrm{RDF}$ 化やゴミ発電の場合と比較して少ないことも理 解される。

しかしながら, 発電用燃料としてのエネルギー変換 効率は重油と同等な油化が最も優れ, 次いで RDF 化, 
そして一般ごみと混ぜて燃焼させるゴミ発電で最も低 くなると考えられる。評価の際には必要に応じてこの 製品の利用形態を考慮に入れる必要がある。例えば, ゴミ発電に関しては，収集されたエネルギーの高々 20\%（スーパーごみ発電で 30\%）程度が電力に変換さ れることになる ${ }^{15)}$ 。

\section{5. プラスチック処理の経済性評価}

廃プラスチック処理の経済性の評価についてもライ フサイクルエネルギーの場合と同様に，プラスチック 排出分布に基づいて計算される収集運搬費用（以下で は，収集費用と呼ぶ）を中心として総合的な評価を行 った。

具体的には，地方自治体のゴミ処理に関する経費を 基に，以下に示すように各費用を目的別に分類するこ とにより，廃プラスチック収集を新たに始める場合の 追加費用の計算方法を定める。また，括弧内には京都 市の年間予算額を参考に記す。

（1）事務人件費および研究人件費 :

リサイクルの有無に依存しない（38 億円）

（2）収運人件費，車両費および収運委託費：

収運の回数に比例（109 億円）

（3）収運費（燃料等）：

収運の走行距離に比例（28 億円）

（4）処理人件費，処理費および処理委託費：

ゴミ処理量に比例（70 億円）

（5）処分人件費，処分費および処分委託費：
埋立量に比例（6 億円）

ここで, 上記の収運の回数や走行距離には, 3.1 節 の収集モデルによる計算結果を用いる。なお,ここで は建設費等の設備関連費用は費用計算に含めず，維 持・管理費のみを評価対象とする。また，各種処理方 法や中間処理の費用については, 神奈川県小田原市の 業者委託費 ${ }^{10)}$ を参考に算出することとし，リサイク ルに伴う収益については, 考察の際に検討に含めるこ ととする。

PET ボトルについての経済性評価結果を Fig. 9 に 示す。PET ボトルの再生利用に際しては PET ボトル の単独収集を想定しているため, 収集費用が膨大とな りバージン材の製造費用を谣かに越えていることが理 解される。なお, 焼却処理の場合には他のゴミと分別 されずに収集されるため, PET ボトルの収集費用も 小さな值にとどまる。このことから，PET ボトルの 再生利用を経済的に成り立たせるためには, 収集の費 用を低減することが重要といえる。また，Fig. 10 に は, メッシュ区画ごとに，人口密度と PET 収集費用 との関係を評価した結果を示す。この図より，区画に よっては，収集費用が PET 樹脂価格 180 [円 $/ \mathrm{kg}$ ］を 下回るところが存在し, 特に人口密度が 1.5 [万人 $\left./ \mathrm{km}^{2}\right]$ 以上のところで，その割合が大きくなってい ることが理解される。すなわち, 人口稠密地域では, PET 再生処理が経済的に見ても成立しうることが示 されたといえよう。

Fig. 11 にはPEに関する経済性評価結果を示す。

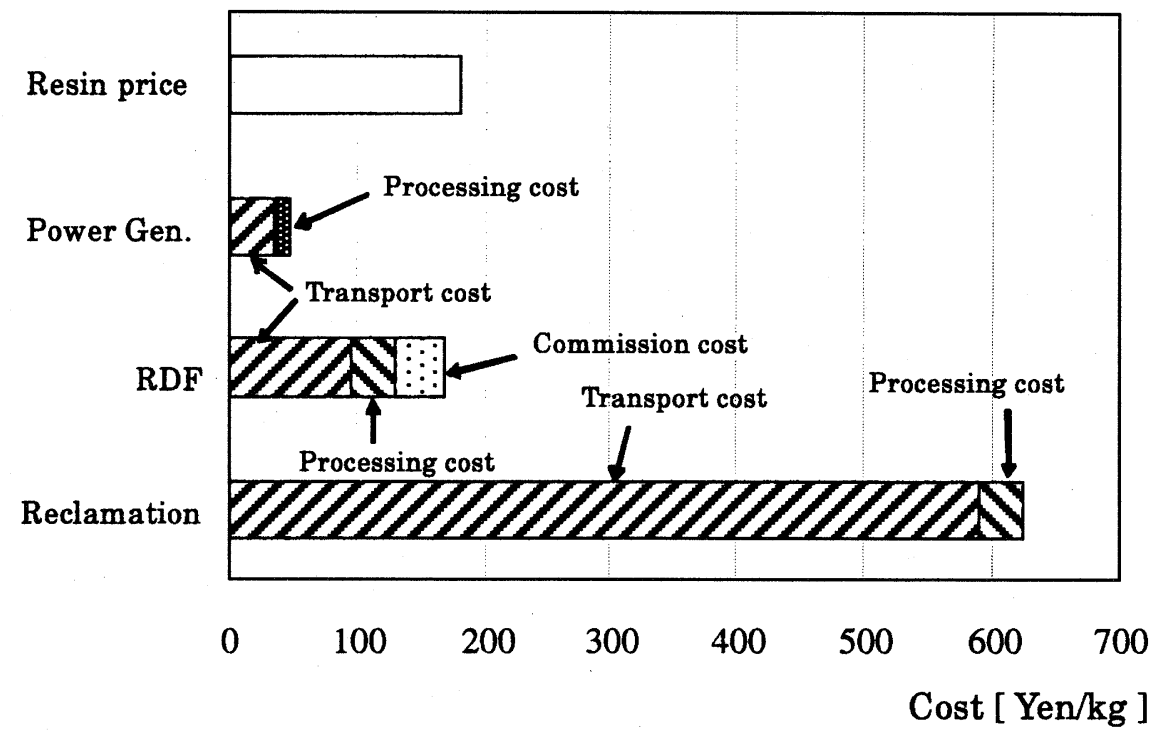

Fig. 9 Economic analysis of PET recycling 


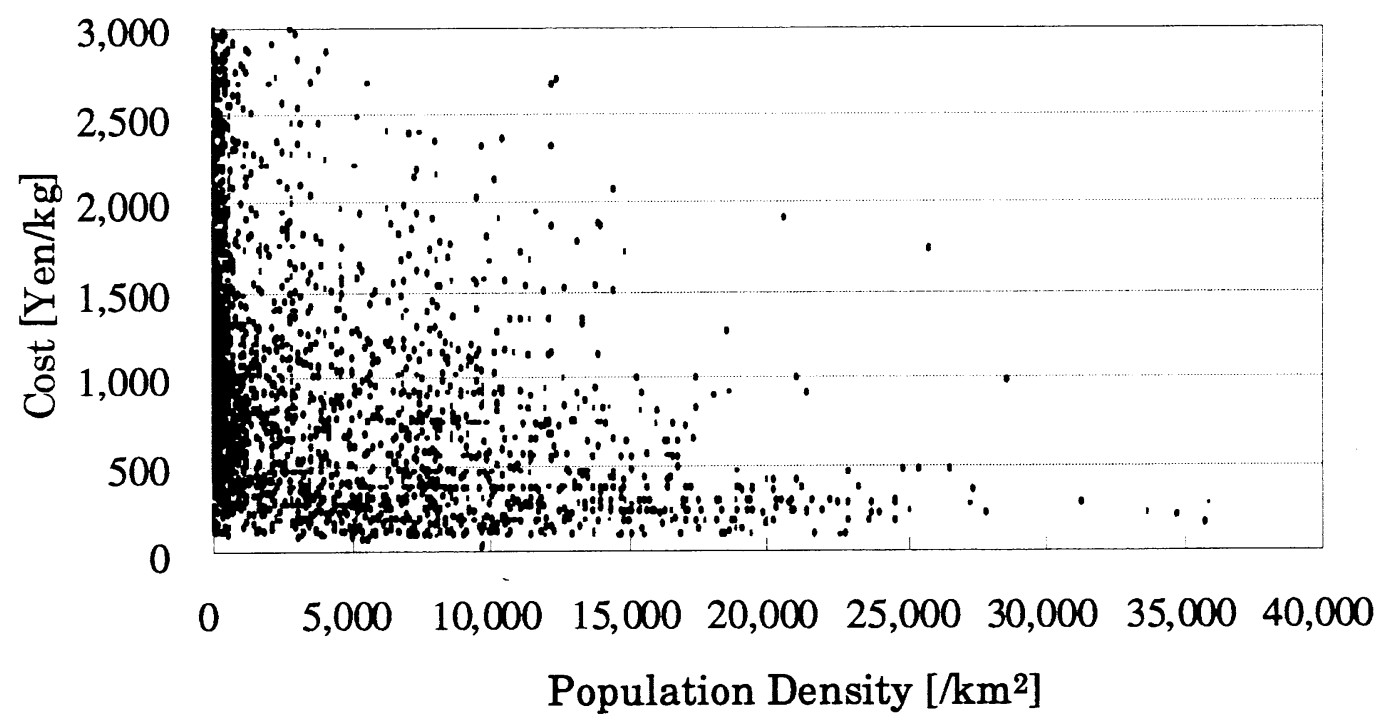

Fig. 10 Relationship between transportation cost and population density

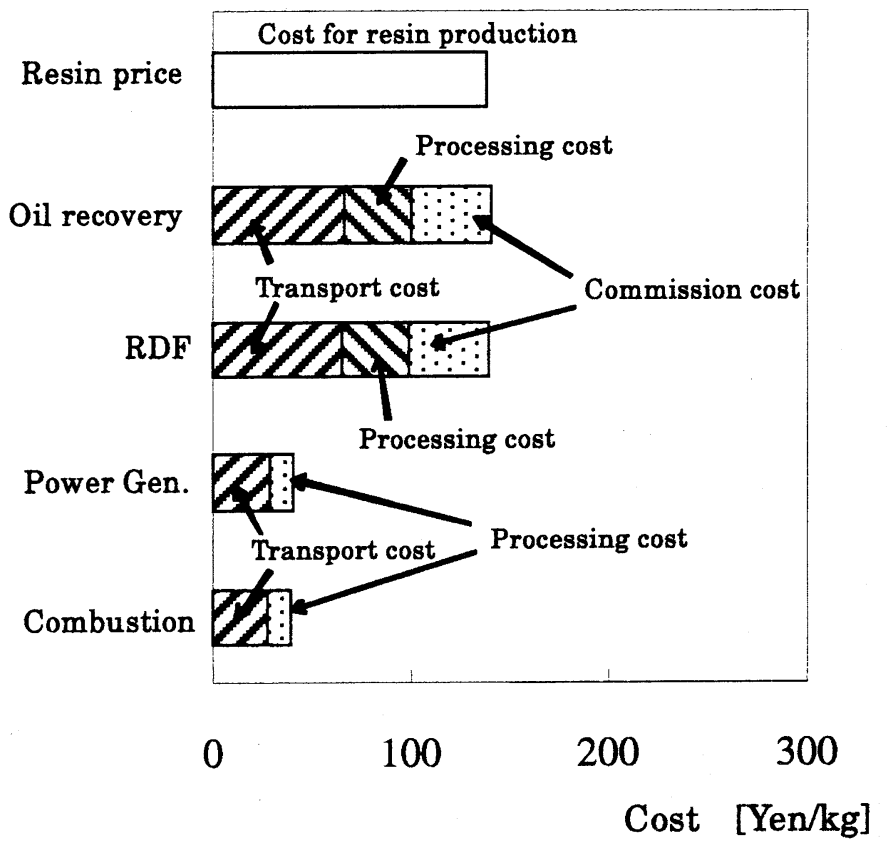

Fig. 11 Economic analysis of PE recycling 
PE に関しては各種熱利用について経済的比較を行っ たが，油化，RDF 化については樹脂製造とほぼ同じ ぐらいの費用が必要となることがわかる。

\section{6. プラスチックリサイクルの費用対効果分析とそ の考察}

前節までの結果に基づいて各リサイクル技術ごとに 計算された，単位費用当たりの節約・収集可能エネル ギー量を Fig. 12 に示す。

Fig. 12 からは，可燃ゴミとの混合ゴミ発電が最も 費用対効果に優れ, 単位重量当たりの節約エネルギー に最も優れていた PET 再生利用が，費用対効果では 劣ることが示されている。また熱収集の方策を採る場 合では, 中間処理を行わずに直接利用する形態の方が, 費用対効果に優れていると言える。

ただし前述したように, 油化, RDF化, ゴミ発電 に関しては燃焼時の発熱量で評価しており，実際には 燃料使用時の発電効率などの違いを考慮に入れて考え る必要がある。また一方では，再生利用に関しても製 品の経済的価值を考慮する必要がある。再生品やごみ 発電電力の買い取り価格に関しては非常にばらつきが 多く明確な議論は容易ではないが，おおよその買い取 り価格として，単位重量のプラスチックあたり油化製 品で $15[$ 円 $/ \mathrm{kg}]$, ごみ発電で 30 [円 $/ \mathrm{kg}]$, PET の再 生樹脂が $100[$ 円 $/ \mathrm{kg}]$ と現状の平均值と思われる值 を設定しても，Fig. 12 における技術間の順序関係は 変わらない。

しかしながら PETの再生利用については収集費用

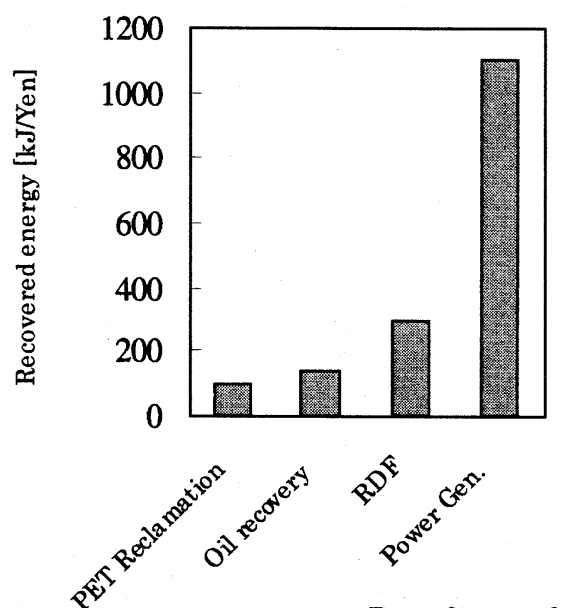

Recycling technologies

Fig. 12 Recovered energy per unit cost by recycling technology
に大幅な削減の余地があり，運搬方法の改善次第では 費用対効果に優れた処理技術になりうる可能性があ る。まず，前節で述べたように人口稠密地域では，経 済的に成立可能性があり，大阪市のみでの回収とした 場合でも, 収集費用が 280 [円 $/ \mathrm{kg}]$ に削減できるこ とが示される。また, 収集用トラックの積載量を 2 倍 にした場合には $225[$ 円 $/ \mathrm{kg}]$ にすることができ，い ずれも Fig. 9 の無対策ケースである 580 [円 $/ \mathrm{kg}]$ の 半分以下にすることができる。すなわち, 人口稠密地 域で収集方法を工夫することにより, 経済的に見て成 立するシステムを構築することができると考えられ る。

また，PETリサイクルプラントの規模を小さくす ることも, 収集費用を削減する上で効果的と考えられ る。この点については, 規模の経済とのトレードオフ 関係の分析が必要となるため, 今後の課題とした。

さらに，もしエネルギー消費量の削減が望ましいと 考えるのであれば, 経済性評価の結果が省エネルギー 性の評価結果と類似の結果をもたらすような社会制度 を，地方自治体として構築すべきであるともいえよう。 プラスチック処理費用 580 [円 $/ \mathrm{kg}$ ］に対する削減の 議論であるため, その社会制度としては, 高々数十 [円 $/ \mathrm{kg}$ ] 程度の削減効果しかもたない炭素税の適用 よりも, 消費者に PET ボトルの回収を義務付ける直 接規制やデポジット制などのインセンティブ規制が有 効と考えられる

一方，油化や RDF 化のように複雑な加工工程を含 むケミカルリサイクルシステムには, エネルギー消費 量, 費用, 費用対効果の何れについても最も優位な技 術とはならなかった。これは, 複雑な処理を含む場合 には, 処理製品の高付加価值化が不可欠であることを 示すものといえよう。

\section{7. おわりに}

本論文では廃プラスチックの各種リサイクルシステ ムに関し，エネルギー消費量や経済性の両面からの評 価を, プラスチックの収集運搬に着目して, 廃プラス チック排出分布に基づいて実施した結果を述べた。

また, 本論文ではミクロ経済の視点からの評価結果 を示したが, 効果的な廃プラスチックのリサイクルシ ステムの考察には, ミクロ経済のみならず, 合成の誤 謬を避けるためにもマクロ経済をも含めた総合的な評 価が必要と考えられる。この点については今後の課題 としたい。

な押, 本研究は, 未来開拓学術研究推進事業「環境 
負荷低減化を目的とした新しい自律分散型都市エネ ルギーシステム」の補助を受けて行われたものであ る。

\section{文献}

1 ）社)プラスチック処理促進協会，プラスチック製 品・廃棄物・再資源化フロー図 (1998 年)

2 ) (社)プラスチック処理促進協会, プラスチックー 般廃棄物を対象とする LCA 的考察 (1995)

3 ）包装廃棄物のリサイクルに関する定量的分析研究 会, (株) 野村総合研究所, 包装廃棄物のリサイク ルに関する定量的分析（1995）

4 ) (財) 統計情報研究開発センター, 平成 7 年度国勢 調査・平成 8 年度事業所. 企業統計調査 地域义 ッシュ統計リンク結果

5 ) (財) 統計情報研究開発センター, 平成 8 年度事業 所・企業統計調查地域メッシュ統計

6) 武本, 太田, 谷川, 阿波, 平成 9 年度排出源等ゴ 乏総合調査, 東京都清掃研究所研究報告, 第 27 号, pp.27-41 (1997)
7）(社) 全国都市清掃会議，一般廃棄物処理事業実態 調查平成 7 年度実績調査デー夕

8 ）(財) 日本環境衛生センター, Fact Book 廃棄物基本 デー夕集 1999

9)上野明, リサイクル団体の現状と見通し 12 , PLASPIA, No.103, pp.45-52 (1998)

10）財 日本環境衛生センター, 容器包装リサイクル 法分別収集事例集（II）(1999）

11）(社) プラスチック処理促進協会，次世代廃プラス チック油化設備 新潟プラスチック油化センター, PLASPIA, No.97, pp.33-36 (1997)

12）公共投資総研，ゴミ処理広域化計画－西日本編一 (2000)

13）社) プラスチック処理促進協会，プラスチックー 般廃棄物を対象とする LCA 的考察 (1995)

14）(社)プラスチック処理促進協会, 平成 10 年度廃 棄物燃料化事業普及基盤整備調查報告書（1999）

15）(社) プラスチック処理促進協会，実用期に入った スーパーゴミ発電, PLASPIA, No.101, pp. 2932 (1998) 


\title{
Economic Analysis of Plastic Recycling System Based on the Wastes Distribution
}

\author{
Sota MACHIDA *1, Tetsuo TEZUKA * ${ }^{*}$, and Takamitsu SAWA *2 \\ $\left(\begin{array}{ll}* 1 & \text { Department of Socio-economic Energy Science, Graduate } \\ & \text { School of Energy Science, Kyoto University } \\ * 2 & \text { Institute of Economic Research, Kyoto University }\end{array}\right)$
}

SYNOPSIS : - Recycling of plastics has been attracting much attention in Japan and also in foreign countries. Recycling system is not easily introduced mainly due to its expensive cost. Economic evaluation of recycling, however, has not been fully investigated in Japan. In this study, fractionation, collection and processing of plastic waste in the residential and commercial sectors are taken into account. Especially the plasticswaste collection has been modeled quantitatively by using the regional mesh statistics and the reports on office survey provided by the Japanese government. Various kinds of plastics-recycling processes are evaluated from the viewpoint of both of life-cycle energy and economics. The evaluation results can be summarized as follows:

The PET reclamation has good performance of energy saving. However, it takes a lot of cost for collection, and this technology is not economically acceptable even if the recycled resin has the same value as the virgin one. Some simulations show that cost reduction is possible by decreasing the labor hour for plastics collection. Furthermore, some measures for voluntary collection of PET containers are most effective if the government thinks the plastics recycling is preferable from the viewpoint of the local and global environment.

\section{Key Words}

Plastics recycling, Economic evaluation, Regional analysis 